\title{
Gender, Effect of Meditation on Anxiety
}

\section{Purushottam Borkar*}

Associate Professor in Psychology, SRM College of SW, Chandrapur, Maharashtra, India

*Corresponding Author: Purushottam Borkar, Associate Professor in Psychology, SRM College of SW, Chandrapur, Maharashtra, India.
Received: September 27, 2021

Published: January 31, 2022

(C) All rights are reserved by Purushottam

Borkar.

\begin{abstract}
Meditation means daydreaming or to engage oneself in imaginary things. Meditation is such an incantation, which calms the mind and settles it. we see all sides of your personality and existence, rather closely. Meditation is an altogether different technique to work accurately and minutely for achieving this. It removes the muscular tension, and these become relaxed. Anxiety is a basic cause of many physical and mental ailments. A person with anxiety feels the world around him as treacherous, insecure and threatening. In this research sample, total 400 men and women, in whom 200 men-women were non- meditated, while 200 men-women were meditated groups. The age group of these selected men and women was 40 to 45 and there social and economic status was of middle class. For this Sinha comprehensive Anxiety Test (SCAT) was used to collect data. it is concluded that the persons (women-men) who are involved in meditation experience low anxiety than persons (women-men) who are not involved in meditation. There exists a significant difference between pre training of meditation and post training meditated individuals.
\end{abstract}

Keywords: Meditation; Anxiety; Gender

The word 'Meditation' is used in different ways. Hence there is a misunderstanding amongst many people, as to what is exactly meant by meditation and how to practices it. Some think that meditation means to think over something by concentrating on it. While some feel that a stage of meditation means daydreaming or to engage oneself in imaginary things. These are all misunderstandings about meditation. In fact, 'Meditation' is a very different process; and it is very important to know it completely.

Meditation is such an incantation, which calms the mind and settles it. It creates a feeling of awareness. This awareness is entirely different from that awareness, which we experience normally, while living in the external world. In meditation, you are completely awakened and cautions; but at the same time you are non-attentive towards the external world or the incidents around you. However, it does not mean that our mind is in a sleeping stage, seeing dreams or engrossed in imaginary things. On the other hand, your mind had become calm and concentrated.
The root of the word 'meditation' is similar to the root of the word 'medical' or 'medicate'. The roots of all these words mean 'to give attention to something' or 'to work on it'. In meditation, we see all sides of your personality and existence, rather closely. These all such things are unknown to us. Our existence is and awareness about the level's existent deeply. These deep levels are very important. These deeply embedded levels are more mature than the process of thoughts, analyzing something, daydreaming or experiencing emotions and various remembrances. These are more effective. Body, mind and respiration are the three parts of our existence.

Meditation is a treatment method, which also strengthens the health of body and mind. It removes the muscular tension and these become relaxed. Similarly, it enhances the working capacity of nervous system and mind becomes tension free. When the mind thus becomes calm and saturated, then the resistance power in the body is not consumed to face the tension. 
Meditation is also fruitful from the health point of view. In the present modern world, the root of many diseases is in the mental, emotional stage. Such ailments cannot be cured by any of the traditional medicines or mental treatment, because if the root cause of your disease is embedded in your mind or your emotions, then it cannot be cured by external methods. Meditation makes people more self-sufficient. They gain in their strength of soul. As a result, they become more competent to face the problems of life.

When we refer meditation, we do remember the ancient sages, monks, sadhus and Buddha. In the modern times, as worries are harassing the human beings, we find thousands of people participating in yoga camps. When some people running after the material wealth, experience worries acutely, a new awareness develops for mental peace and health then they participate in such meditation camps. 'Meditation' is nothing but a technique to reduce mental worries and to extend self-awareness on a wide scale. Maharshi Mahesh Yogi has called it as 'Inert knowledge' keeping aside the religious and spiritual factors. Hence, in present times meditation is used to acquire a peaceful and relaxed condition devoid of worries and for developing a healthy body. Meditation is a means of achieving personal development in human life.

It is an art to acquire health, vigor, cheerfulness and joy. It therefore strengthens the skillfulness and the willpower and creates a competence to fulfill difficult tasks. Those persons, who meditate regularly, can enjoy joy from freedom of worries.

\section{Anxiety}

According to psychologists, anxiety is a basic cause of many physical and mental ailments. Even the modem medicine has accepted this fact. Indians know since ancient times, what is anxiety. This becomes clear from the following lines.

"Chita DahatiNirjeevam, Chinta Jeevan Dahati Vridhivadhika chinta,chita tyalahi Bhutale |"

The above lines mean - a pyre buries a dead person, while the anxiety burns a man in his lifetime. There is a difference of only a 'dot' in both these words. On this Earth, the extent of pyre is much less than anxiety. In the present times, this anxiety is spreading by leaps and bounds, as the urban life has become too fast. For the treatment of anxiety, more and more foreigners are turning to Indian Yoga Shastra or science and as a result these classes of 'Yogasana' and meditation are becoming extremely popular there. A person with anxiety feels the world around him as treacherous, insecure and threatening. Then an unknown fear starts torturing him about such world. Hence, such person always feels, that something bad and adverse will take over him.

\section{Definitions}

Anxiety is defined by Barlow, (2002) [4] as "an uncontrollable, diffuse, unpleasant, and persistent state of negative effect, characterized by apprehensive anticipation regarding unpredictable and unavoidable future danger, and accompanied by physiological symptoms of tension and constant state of heightened vigilance."

Anxiety always results about future incidents i.e., anxiety is related to future. We can differentiate between anxieties felt by a common man e.g., the student feels anxiety for examination. Here, we cannot tell the reason definitely, hence such anxiety can be solved. However, deformative anxiety is created without any reason. Here the nature of anxiety is at personal level and the victim cannot tell why it is created. As such, such anxiety cannot be cured.

\section{Kinds of anxiety}

Spielberger [24] has studied the importance of concept of anxiety. According to him, anxiety is mainly of two kinds.

\section{State Anxiety}

The anxiety of this kind is an emotional reaction in changing forms according to different occasions. Similarly, there occurs a change in this kind of anxiety as per times and circumstances.

\section{Trait anxiety}

The anxiety of this kind forms a special factor of the person's personality. This anxiety exists differently and in more or less extent in the person. A person, though he may be under any circumstances, this type of anxiety exists in that person.

Spielberger [24] studied importantly both types of anxieties and showed more clarity about both. This study was regarding the anxiety of such patients, who were to be operated. In his study he found that the extent of state anxiety was more in such patients before operation. While, after the operation, the extent of state anxiety was reduced and there was no change in the trait anxiety. This study further showed that the state anxiety was similar to the extent of acuteness of the reward.

- The persons suffering from anxiety shows shivering in the 
body, stomachache etc.

- Due to continuous anxiety, heart attack, Brain hammerage and disturbance in the digestive system like indications are seen.

- Anxiety disturbs sleep. Similarly, irritation, headache, lack of concentration and bad dreams are observed as indications of more anxiety and fear.

\section{Effects of Anxiety}

- Anxiety disturbs the balance of hormones in the body and as a result many mental and physical problems are created of surprising and complicated nature.

- Anxiety shows irregularity in the monthly course (menstruation cycle) of women and it given rise to irritation in them.

- Anxiety slows down the person's hunger or such person takes more food intake. As a result, such person becomes either weak or fat.

- Anxiety creates uneasiness, increases extent of fear; as a result, there is an adverse effect on the person's capacity and work competence.

- As such if a person is not healthy on a mental level, he lowers down his prestige in the society.

- A person continuously suffering from anxiety is avoided by others and he is left alone for life struggle.

According to Kabat-Zinn [17] have clarified through their research that, meditation gives them mental peace. Similarly, by doing meditation, a man achieves concentration and by protecting himself, brings his mental and physical progress. Arond (2006) [2] has said in his shaktipeeth meditation research that, by doing shaktipeeth meditation concentration develops and as a result mental strength is acquired. Similarly, it increases the thinking capacity, the mind becomes calm, and by reducing anxiety, disappointment and mental tension, it increases self-confidence. All these are achieved only through the regular practice of meditation. NIMH (National Institute of Mental Health) (2009) when this institution made a project on meditation practice and depression, it was found that, depression is present in every woman-man, according to their physical and mental capacity. Under it, feelings like acute sorrow, anxiety, a feeling of loneliness, a feeling of guilt, not to help anybody, un-peacefulness, dislike for the work, loosing mental concentration as well as fear, Insomnia and sometimes thoughts of committing suicide, severe headache etc. are experienced. It was found in this project that all these problems were reduced by the regular practice of the meditation. Epstence (2003) [9] said in his research, that while doing medical practice, meditation and mindfulness therapy helps the clients (patients) to make them healthy. This therapy also helps to take decision during uncertain situations and can increase the self-confidence of the clients. The ancient tradition of yoga and meditation began in Indian prehistory as a system of mental, physical and spiritual exercises. In approximately $500 \mathrm{BC}$ the physician and sage Patanjali formalized this tradition into a science with four major and four lesser branches involving ethical restraint, self-discipline, mental focus and physical exercise and meditation.

The entire system was used in an integrated fashion and directed at the attainment of a unique state of spontaneous, psychological integration. Similarly, Falcone (2008), [11] Tibetan Buddhist meditations can be concentration enhancement exercises or elaborate Tantric deity visualizations, but sometimes they are "analytical meditations" in which worldly norms are deconstructed through logic: "meditation on impartiality," "meditation on love," "meditation on attachment" and "meditation on impermanence."

\section{Method}

One finds that woman-men are suffering from anxiety, tension and distress (disappointment), they are not contented in their life, and they lack self-confidence. As such, it is the need of the hour to study the meditation through a scientific perspective.

\section{Objectives of study}

- To find out the effect of meditation on anxiety.

- To study the effect of meditation on the part of males and females.

- $\quad$ To study the difference in meditation before meditation and after the meditation training.

Problems for research

- How does meditation affect anxiety?

- What is the before and after effect of meditation?

Variables

- Independent Variables: Meditation, Gender.

- Dependent Variables: Anxiety, 
Hypotheses (Assumptions)

- The people without meditation suffer more from anxiety, than those people who regularly do meditation.

- $\quad$ There will not significantly difference between meditation and non-meditating males and females.

- $\quad$ There will be significant difference between pre training of meditation and post training meditated individuals.

Sample

In this research sample, total 400 men and women, in which 200 men-women were non meditated, while 200 men-women were meditated groups. Taking into consideration these two variables, for studying main and interactions of persons with the constitutional aspects two groups were made doing meditation: of 100 men and 100 women. The age group of these selected men and women was 40 to 45 and there social and economic status was of middle class.

Tools used

Following psychological tests were used according to objectives under the present research.

SCAT

Scale: Sinha comprehensive Anxiety Test (SCAT) by A.K. Sinha and L.N.K. Sinha. This is a test of oral statement nature. Reliability is 0.62 to 0.92 .

Procedure

Before acquiring actual statistics, permission was obtained from authorities. Afterwards selected men and women were instructions to take test. In this way, data were collected from men - women meditation and men - women non meditated, of all 4 groups.

\section{Variables under study}

In the present research, meditation and gender were considered as independent variables, while Anxiety was considered as dependent variables.

\section{Statistical Analysis and Interpretation}

In the present research work, two independent variables i.e., sex and meditation on Anxiety and also to observe the main and interactive effect, these were divided into four groups. In this each group, 100 persons (women and men) were selected. In this way composite groups of four kinds were made as follows.

$A_{1} B_{1}$ (Male/Meditated), $A_{1} B_{2}$ (Male/Non-Meditated, $A_{2} B_{1}$ (Female/Meditated), $A_{2} B_{2}$ (Female/Non-Meditated).

In the present research by using statistical technique, classification of two-way ANOVA are as follows.

\section{Two-way analysis of variance (ANOVA) on factor SCAT}

' $\mathrm{A}$ ' the main effect in the main effect table shows comparison between men and women and also shows average on two levels on ' $\mathrm{B}$ ' for main effect ' $A$ ', the $F$ value is 13.75 , for which $\mathrm{df}=1$ and $\mathrm{df}=396$ are there. This expected table value should be 6.70 for 0.01 level while obtained F value is 13.75 is found significant at 0.05 level, it is concluded that, men and women differ significantly in Anxiety.

The main effect ' $\mathrm{B}$ ' is with respect to meditation and its average has been presented on two levels of ' $B$ '. The values obtained for effect ' $\mathrm{B}$ ' are $\mathrm{F}=11.21$ and $\mathrm{df}=2$ and $\mathrm{df}=396$. The value obtained is more than $F=6.70$, this value shows that women and men who does meditation differs significantly than those who are not involved in meditation in case of Anxiety, while the mean score of male female meditated group namely 19.72 and for second group 22.76, which is lesser than the mean score of non-meditated male females, 22.51 and 24.62 as such it is concluded that the persons (women-men) who are involved in meditation experience low anxiety than persons (women-men) who are not involved in meditation [1-25].

AxB the interaction effect was not found to be significant $F$ value obtained for this interaction (0.44) is insignificant at 0.05 levels.

\begin{tabular}{|c|c|c|c|}
\hline Classified group & $\mathbf{N}$ & Mean & Sd \\
\hline $\mathrm{A}_{1} \mathrm{~B}_{1}$ & 100 & 19.72 & 5.62 \\
$\mathrm{~A}_{1} \mathrm{~B}_{2}$ & 100 & 22.51 & 7.43 \\
$\mathrm{~A}_{2} \mathrm{~B}_{1}$ & 100 & 22.76 & 7.23 \\
$\mathrm{~A}_{2} \mathrm{~B}_{2}$ & 100 & 24.62 & 7.18 \\
\hline
\end{tabular}

Table 1: Means, Standard deviation of classified group. 


\begin{tabular}{|l|c|c|c|c|}
\hline Source of variation & SS & Df & MS & F \\
\hline A (Sex) & 663.06 & 1 & 663.06 & $13.75^{* *}$ \\
B (Meditation/non-Meditation) & 540.56 & 1 & 540.56 & $11.21^{* *}$ \\
AxB & 21.63 & 1 & 21.63 & 0.44 \\
Within & 19092.95 & 396 & 48.21 & (NS) \\
\hline Total & 20318.20 & & & \\
\hline
\end{tabular}

Table 2: Two-way analysis of variance of classified group.

$$
\begin{aligned}
& \qquad * *(\text { Significant at } 0.01 \text { level }) \\
& \qquad * *(\text { Significant at } 0.05 \text { level }) \\
& \text { Value required to be significant at } 0.05 \text { level }=3.86 \\
& \text { Value required to be significant at } 0.01 \text { level }=6.70
\end{aligned}
$$

\section{Conclusions}

From the above observations, it was concluded that, the people engaged in meditation regularly suffer less from anxiety, than the people who do not meditate. Further, there is significant difference between meditating and non-meditating males and females and had a positive effect of meditation on both women-men. Simultaneously, this study showed positive and affirmative effect after meditation.

\section{Limitations}

The research was conducted on middle age peoples between 40 to 45 years. Further the study is conducted in vidharbha region of Maharashtra. Since the age group and area is limited here the results cannot be generalized to other populations.

\section{Bibliography}

1. Alexander CN and Orrne-Johnson DW. "Walpole study of the transcendental meditation program in maximum security prisoners II: Longitudinal study of development and psychopathology". Journal of Offender Rehabilitation (2003).

2. Arond D. "The Practice of Mindfulness Meditation to Alleviate Symptoms of Chronic Shyness and Social Anxiety". Dissertation Abstracts international: section B. The science and Engineering 67.5-B (2006): 2822.

3. Asher R and Bronstein F. "Melding Meditation and Painting in Merrimack Valley". The Jewish Journal Boston North (2008).
4. Barlow DH. "Anxiety and its disorders: The nature and treatment of anxiety and panic (2nd Ed.)". New York: Guilford press (2002).

5. Baer RA. "Mindfulness Training as a clinical intervention: a conceptual and empirical review". Clinical Psychology: Science and Practice (2003).

6. Christopher $M$ and Gilbert B. "Incremental validity of cononents of mindfulness in the prediction of satisfaction with life and depression". Current Psychology: Research 29.1 (2009): 10-23.

7. Davidson RJ. "The Physiology of Meditation and other states of consciousness". Perspectives in Biology and Medicine (1976).

8. Epstein RM. "Cultivating Habits of Mind, Families, Systems and Health, Mindful action in practice 19.3 (2003): 345-380.

9. Easterlin BL and Cardena E. "Congitive and emotional differences between short and long-term, Vipassana Meditators. Imagination". Congnition and Personality 18.1 (1999): 68-81.

10. Emavardhana J and Tori CD. "Changes in self-concept, ego defense mechanisms, religiosity following seven day, Vipassana meditation retreats". Journal for the Scientific Study of Religion 36.2 (1997): 194-206.

11. Falcone J. "A meditation on meditation". Anthropology News 49.1 (2008): 15-16. 
12. Fujita F and Diener E. "Life satisfaction set point: stability and change". Journal of Personality and Social Psychology 88.1 (2005): 158-164.

13. Gerstorf., et al. "Decline in life satisfaction in old age: Longitudinal evidence for links to distance-to-death". Psychology and Aging 23.1 (2008): 154-168.

14. Goldstein J and Komfield J. "Seeking the heart of wisdom: the path of insight meditation". Boston: Shambhala (1987).

15. Goleman D. "Meditation and consciousness: An Asian approach to metnal health". American Journal of Psychotherapy 30.1 (1976): 41-54.

16. Iyengar BKS. "Light on the Yoga Sutras of Patanjali". London: Thorsons (1996).

17. Kabat - zinn J., et al. "Four-Year follow-up of a meditationbased program for the self-regulation of chronic pain: Treatment outcomes and compliance". Clinical Journal of Pain 2.3 (1987): 159-774.

18. Kornfield J. "The seven factors of enlightenment. In R. Walsh and F. Vaughan (eds), Paths beyond ego: The transpersonal vision". Los Angeles: Tarcher (1993).

19. Lee SH., et al. "Effectiveness of a meditation-based stress management program as an adjunct to pharmacotherapy in patients with anxiety disorder". Journal of Psychosomatics Research 62.2 (2007): 189-195.

20. Novak P. "Buddhist Meditation and the great chain of being: Some misgivings". Listening 24.1 (1989): 67-78.

21. Dalai Lama. “A Policy of Kindness". Ithaca: Snow Lion (1993).

22. Shapiro SL and Schwartz GE. "Mindfulness in medical education: Fostering the health of physicians and medical practice". Integrative Medicine 1 (1998): 93.

23. Spielberger CD., et al. "Manual for The State, Trait Anxiety Inventory Palo Alto". CA: Consulting Psychologist Press (1978).

24. Sridevi K., et al. "Temporal effects of meditation and personality". Psychological Studies 43.3 (1998): 95-105.

25. Williams P and Tribe A. "Buddhist thought: A complete introduction to the Indian tradition". New York: Routledge (2002).

\section{Assets from publication with us}

- Prompt Acknowledgement after receiving the article

- Thorough Double blinded peer review

- Rapid Publication

- Issue of Publication Certificate

- High visibility of your Published work

Website: www.actascientific.com/

Submit Article: www.actascientific.com/submission.php

Email us: editor@actascientific.com

Contact us: +919182824667 